\title{
ANALISIS PENGARUH CORPORATE SOCIAL RESPONSIBILITY PADA KINERJA KEUANGAN DENGAN MANAJEMEN LABA SEBAGAI VARIABEL PEMODERASI
}

\section{ANALYSIS OF THE EFFECT OF CORPORATE SOCIAL RESPONSIBILITY IN FINANCIAL PERFORMANCE WITH EARNING MANAGEMENT AS A MODELING VARIABLE}

\author{
Sri Ruwanti ${ }^{1}$ dan Prima Aprilyani Rambe ${ }^{2}$ \\ 1)Universitas Maritim Raja Ali Haji - Tanjungpinang \\ 2)Universitas Maritim Raja Ali Haji - Tanjungpinang \\ Email : sriruwanti@yahoo.com dan aprilyaniprima@gmail.com
}

\begin{abstract}
ABSTRAK
Penelitian ini bertujuan untuk memperoleh bukti empiris mengenai pengaruh manajemen laba terhadap aktivitas Corporate Social Responsibility dan dampak dari manajemen laba dan Corporate Social Responsibility terhadap kinerja keuangan perusahaan manufaktur. Penelitian ini menggunakan 40 perusahaan yang terdaftar di Bursa Efek Indonesia selama periode 2011 2015. Teknik penarikan sampel menggunakan purposive sampling. Penelitian ini menggunakan regresi linier berganda. Hasil penelitian pada hipotesis pertama menunjukkan bahwa Corporate Social Responsibility tidak berpengaruh pada kinerja keuangan. Hasil hipotesis kedua menunjukkan bahwa manajemen laba baik riil maupun diskresioner tidak berpengaruh padaCorporate Social Responsibility. Hasil hipotesis ketiga menunjukkan bahwa Corporate Social Responsibility yang dihubungkan dengan manajemen laba riil berpengaruh pada kinerja keuangan namun Corporate Social Responsibility yang dihubungkan dengan manajemen laba discretionary accruals tidak berpengaruh pada kinerja keuangan.
\end{abstract}

Kata Kunci : corporate social responsibility, manajemen laba, kinerja keuangan

\begin{abstract}
This study aims to obtain empirical evidence on the effect of earnings management on Corporate Social Responsibility activities and the impact of earnings management and Corporate Social Responsibility on the financial performance of manufacturing companies. This study used 40 companies listed on the Indonesia Stock Exchange during the period 2011-2015. Sampling technique using purposive sampling. This research uses multiple linear regression. The results of the first hypothesis show that Corporate Social Responsibility does not affect financial performance. The result of the second hypothesis shows that both real and discretionary earnings management do not affect Corporate Social Responsibility. The result of the third hypothesis indicates that the Corporate Social Responsibility associated with practical earnings management affects the financial performance. Still, the Corporate Social Responsibility related to earnings discretionary accruals management does not affect financial performance.
\end{abstract}

Key words: corporate social responsibility, earnings management, financial performance 


\section{PENDAHULUAN \\ Latar Belakang}

Tujuan utama perusahaan didirikan adalah untuk mencapai laba. Seringkali laba dijadikan sebagai dasar untuk pengambilan keputusan. Baik keputusan yang terkait dengan pengembangan perusahaan, maupun keputusan yang terkait dengan penilaian kinerja manajemen. Manajemen diberi kewenangan untuk mengelola dana yang diberikan oleh investor serta melaporkannya. Mereka berkewajiban membuat laporan keuangan sebagai bentuk pertanggungjawaban kepada investor. Investor menggunakan informasi yang ada di dalam laporan keuangan untuk menilai kinerja manajemen. Olah karenanya, manajemen berusaha untuk menampilkan informasi yang menunjukkan kinerja yang baik. Jarak antara informasi dengan manajemen lebih dekat dibandingkan dengan investor. Dengan adanya informasi yang mereka miliki, mereka menyusun laporan keuangan yang dapat menampung tujuan-tujuan tertentu dari manajemen dalam rangka mempertinggi kemakmuran.

Laporan keuangan dibuat sedemikian rupa untuk menunjukkan kinerja keuangan yang baik dan pencapaian laba yang sesuai dengan target. Laba diatur dengan memanfaatkan fleksibelitas akuntansi. Pilihan-pilihan yang digunakan direncanakan untuk menghasilkan laba sesuai yang ditargetkan manajemen. Pada gilirannya manajemen akan mendapatkan penilaian yang baik dari investor dan memperoleh berbagai kompensasi seperti bonus dan jabatan.

Dalam laporan keuangan yang disajikan, terdapat pengungkapan-pengungkapan peristiwaperistiwa yang mempengaruhi laporan keuangan baik yang bersifat wajib maupun yang bersifat sukarela. PSAK No.1 (2014) paragrap 14 yang berbunyi "beberapa entitas juga menyajikan, dari laporan keuangan, laporan mengenai lingkungan hidup dan laporan nilai tambah, khususnya bagi industri dimana faktor lingkungan hidup adalah signifikan dan ketika karyawan dianggap sebagai kelompok pengguna laporan keuangan yang memegang perananan penting. Laporan yang disajikan di luar keuangan tersebut adalah diluardari ruang lingkup SAK (Ikatan Akuntan Indonesia).

Wibisono (2007:9) menjelaskan bahwa saat ini perusahaan dalam menjalankan bisnisnya tidak hanya mempunyai kewajiban yang bersifat ekonomis dan legal, akan tetapi kewajiban yang bersifat etis berhubungan dengan nilai sosial dan lingkungan. Oleh karena itu, perusahaan harus menerapkan Corporate Social Responsibility (CSR).

Undang-undang No.40 tahun 2007 pasal 74 secara tegas mengatur tentang Corporate Social Responsibility ini yang memuat aturan tentang tanggung jawab sosial dan lingkungan perusahaan. Dimana perusahaan harus memiliki komitmen untuk berperan dalam lingkungan, komunitas setempat maupun masyarakat pada umumnya.

Penelitian Basamalah dan Jeremias (2005), menunjukkan bahwa salah satu alasan manajemen melakukan pelaporan sosial adalah untuk alasan strategis. Du, Bhattacharya dan Sen (2010) mengungkapkan bahwa melalui aktivitas Corporate Social Responsibility, perusahaan tidak hanya menghasilkan prilaku stakeholder yang baik dan prilaku dukungan yang lebih baik, tapi juga dapat membangun citra perusahaan, kekuatan hubungan antara perusahaan dengan stakeholder, serta meningkatkan prilaku dukungan stakeholder. Perusahaan akan memperoleh legitimasi sosial dan memaksimalkan kekuatan keuangannya dalam jangka panjang melalui penerapan CSR (Kiroyan, 2006).

Prilaku dukungan stakeholders muncul setelah pengungkapan CSR dilakukan, sehingga hal tersebut dapat dimanfaatkan oleh manajemen untuk melindungi tujuan-tujuan serta kepentingankepentingannya melalui keterlibatannya dalam aktivitas CSR yang telah dilakukan. Pengungkapan yang dilakukan seoalah-olah mengalihkan perhatian dari tindakan manajemen laba yang dilakukan oleh manajemen. 
Pengungkapan CSR yang dalam laporan keuangan menunjukkan komitmen perusahaan tidak hanya pada pencapaian profit semata namun juga pengembangan kesejahteraan masyarakat serta komitmen terhadap kualitas lingkungan. Apabila informasi tersebut ditangkap secara baik oleh stakeholders maka dapat meningkatkan kepercayaan dan loyalitas kepada perusahaan. Pada gilirannya akan meningkatkan penjualan dan laba, sehingga menghasilkan kinerja keuangan yang baik pula. Penelitian Chen dan Wang (2011), menunjukkan bahwa aktivitas tanggungjawab sosial perusahaan dapat meningkatkan kinerja keuangan mereka tahun berjalan, memiliki efek yang signifikan terhadap kinerja keuangan mereka tahun depan, dan sebaliknya. Variasi CSR dan kinerja keuangan juga dapat secara signifikan mempengaruhi satu sama lain.

Sementara, dalam penelitiannya Mangoting (2007), mengungkapkan bahwa pemerintah melalui Direktorat Jendral Pajak dapat memberikan insentif pajak yang memperkenankan pengeluaran-pengeluaran tanggung jawab sosial sebagai pengurang penghasilan kena pajak untuk perusahaan yang konsisten menerapkan tanggung jawab sosialnya.

Sarumpaet (2005), mengemukakan bahwa tidak ada hubungan yang signifikan antara kinerja lingkungan yang diukur menggunakan ROA (Return on Assets) dan kinerja keuangan perusahaan, akan tetapi ukuran perusahaan, listing di BEJ dan ISO 14001 berhubungan secara signifikan terhadap kinerja lingkungan. Pada penelitian yang dilakukan Sarumpaet, kinerja lingkungan diukur mengunakan rating kinerja lingkungan perusahaan atau PROPER yang disediakan oleh Bapedal/Kementerian Lingkungan Hidup RI, sedangkan kinerja keuangan diukur dengan ROA (Return on Assets).

Irina et al (2010) dalam penelitiannya pada perusahaan Internasional di Roma mengemukakan bahwa secara teori dan pada praktiknya terbukti bahwa CSR dapat meningkatkan komersial bisnis dan kinerja keuangan. Sementara penelitian lain yang dilakukan oleh Demacarty (2009) menyebutkan bahwa baik perusahan yang melakukan Corporate Social Responsibility (CSR) maupun Corporate social Iresponsibility memiliki rata-rata profit yang seimbang. Riset empiris secara umum menunjukkan korelasi positif antara CSR sebagai ukuran dan kinerja keuangan perusahaan. Namun ia juga menambahkan bahwa hal tersebut kemungkinan bukan dikarenakan oleh CSR tapi karena kemampuan manajemen.

Penelitian lain menguji hubungan CSR dengan manajemen laba (earning management). Seperti yang dilakukan oleh Handajani, Sutrisno dan Chandrarin (2009) yang menghasilkan kesimpulan bahwa manajemen laba memiliki pengaruh signifikan pada pengungkapan CSR. Semakin tinggi manajemen laba akan membuat pengungkapan CSR semakin tinggi pula. Manajemen laba merupakan suatu cara yang dilakukan oleh manajemen untuk mengatur besar kecilnya laba dengan memanfaatkan metode-metode dalam akuntansi untuk kepentingan manajer. Dengan adanya mekanisme manajemen laba, dapat diduga pula bahwa hal tersebut juga dapat mempengaruhi kinerja keuangan perusahaan. Karena pengukuruan kinerja perusahaan melibatkan komponen-komponen akuntansi yang salah satunya adalah laba.

Penelitian Rahmawati dan Dianita (2011) menguji hubungan CSR dan kinerja keuangan dengan manajemen sebagai variabel moderating yang menunjukkan hasil bahwa perusahaan yang terlibat dalam praktek manajemen laba tidak memiliki pengaruh pada kegiatan CSR. Selain itu,hipotesis kedua, berdasarkan CSR menjelaskan bahwa kegiatan yang berhubungan dengan praktek manajemen laba berpengaruh negatif terhadap kinerja keuangan perusahaan di masa depan.

Penelitian tersebut memotivasi penelitian yang kami lakukan, namun pada penelitian Rahmawati dan Dianita (2011) manajemen laba hanya diukur dengan menggunakan discretionary accruals, sedangkan kami juga menggunakan real earnings management. Oleh 
karenanya penelitian ini bertujuan untuk menguji manajemen laba dalam memoderasi hubungan antara CSR dan kinerja keuangan, baik manajemen laba akrual maupun manajemen laba riil.

Penelitian ini diharapkan memberikan manfaat kepada perusahaan-perusahaan go public dan pelaku pasar modal terkait informasi-informasi yang dapat menjadi pertimbangan dalam mengambil keputusan investasi dan peningkatan kinerja keuangan perusahaan serta untuk memperkaya bahan ajar terkait dengan topik CSR, manajemen laba dan kinerja keuangan.

\section{KAJIAN PUSTAKA}

\section{Tanggung Jawab Sosial (Corporate Social Responsibility) dan Kinerja Keuangan Perusahaan}

Konsep Corporate Social Performance (CSP) diperkenalkan sebagai sebuah metode pengevaluasian bagaimana organisasi yang baik menemukan tanggung jawab sosial perusahannya (Albinger dan Freeman, 2000).

World Business Council on Sustainable Development (WBCSD) mendefinisikan CSR sebagai sebuah gagasan yang meliputi sosial (misalnya program-program sosial masyarakat), ekonomi (misalnya pekerjaan), dan lingkungan (misalnya pengurangan limbah) aspek dari aktivitas bisnis.

Beberapa penelitian yang terkait dengan CSR dan kinerja keuangan antara lain dilakukan oleh Demacarty (2009) yang menunjukkan bahwa secara umum menunjukkan korelasi positif antara CSR dengan Corporate Financial Performance (CFP). Namun Demacarty juga menyebutkan bahwa pengaruh itu bukan semata-mata karena CSR, tapi mungkin karena management skill.

Yuniarsih dan Wirakusuma (2009), menguji pengaruh kinerja keuangan terhadap nilai perusahaan dengan pengungkapan Corporate Social Responsibility dan Good Corporate Governance sebagai variabel pemoderasi, dimana kinerja perusahaan dinilai dengan ROA yang menunjukkan hasil ROA terbukti berpengaruh posistif secara statistis pada nilai perusahaan, pengungkapan CSR sebagai variabel pemoderasi terbukti berpengaruh secara statistis pada hubungan return on asset dan nilai perusahaan atau dengan kata lain CSR merupakan variabel pemoderasi dalam kaitannya dengan hubungan ROA dan nilai perusahaan, kepemilikan manajerial sebagai variabel pemoderasi tidak terbukti berpengaruh terhadap hubungan Return on Asset nilai perusahaan atau dengan kata lain kepemilikan manajerial bukan merupakan variabel pemoderasi.

Penelitian lain yang dilakukan oleh Rettab, Brick dan Melahi (2009) yang menguji hubungan antara CSR dengan kinerja keuangan, komitmen karyawan dan reputasi perusahaan menunjukkan hasil bahwa CSR memiliki hubungan positif dengan tiga pengukuran kinerja organisasi yaitu kinerja keuangan, komitmen karyawan dan reputasi perusahaan.

Tsoutsoura (2004) menggunakan Return on Asset (ROA), Return on Equity (ROE) dan Return on Sales (ROS) sebagai pengukur kinerja keungan untuk mengetahui hubungan antara CSR dan kinerja keuangan. Hasilnya menunjukkan bahwa ada hubungan yang positif dan signifikan secara statistik antara CSR dan kinerja keuangan. Tsoutsoura juga memasukkan ukuran perusahaan (firm size) sebagai variabel kontrol pada penelitiannya. Menurut Waddock dan Graves (1997) dan Itkonen (2003), company size berhubungan dengan Corporate Social Performance (CSP).

Crisostomo, Freire dan Vasconcellos (2011) menemukan bahwa ada korelasi negatif antara CRS dan nilai perusahaan. Sejalan dengan mereka, Usman dan Amran (2015) meneliti hubungan antara CSR dan financial performance yang menghasilkan bahwa terjadi hubungan 
negatif antara CSR dan CFP. Sebaliknya, penelitian Aras, Aybars dan Kuttlu (2010) menunjukkan hubungan positif antara CSR dan financial performance/profitability.

\section{Manajemen Laba (Earning Management)}

Beberapa definisi manajemen laba pernah diungkapkan oleh banyak peneliti. Manajemen laba merupakan bentuk khusus dari permainan angka-angka keuangan. Pada manajemen laba, fleksibelitas GAAP digunakan untuk menuntun agar laba yang dilaporkan sesuai dengan target yang telah ditetapkan sebelumnya. Target yang ingin dicapai sering kali adalah laba jangka panjang yang tumbuh dan berkesinambungan, tanpa gejolak turun naik yang biasanya nampak sebagai representasi dari proses ekonomi normal (Mulford \& Comiskey, 2010).

Esensi dari manajemen laba yaitu suatu kemampuan untuk memanipulasi pilihan-pilihan yang tersedia dan mengambil pilihan yang tepat untuk dapat mencapai tingkat laba yang diharapkan (Riahi \& Belkaoui, 2006).

Scott (2009) meninjau permasalahan manajemen laba dari dua perspektif, (1) contracting perspective, earning management can be used as a low-cost way of protecting the firm from the consequences of unforeseen state realization in presence of rigid and incomplete contracts. (2) financial perspective, managers may be able to affect the market value of their firm's shares by earning management.

Penelitian Al-Khabash dan Al-Thuneibat (2009) menginvestigasi pandangan auditor eksternal dan auditor internal terhadap manajemen laba. Hasil penelitian menunjukkan bahwa auditor eksternal percaya bahwa manajemen terlibat secara signifikan hanya dalam manajemen laba yang sah baik kenaikan atau penurunan pendapatan. Namun,auditor internal percaya bahwa manajemen terlibat dalam praktek-praktek yang sah yang hanya meningkatkan pendapatan. Dalam kedua kasus, ada perbedaan yang signifikan antara pandangan mereka.

Manajemen laba berpengaruh secara posistif signifikan pada pengungkapan Corporate Social Responsibility setelah dikontrol oleh ukuran perusahaan dan tipe industri (Handajani, Sutrisno, Chandrarain; 2009)

Hasil penelitian Kiattikulwattana (2014) menunjukkan bahwa perusahaan tetap melakukan manajemen dengan atau tanpa adanya pengungkapan tanggungjawab manajemen dalam laporan keuangan. Sementara penelitian Muttakin, Khan dan Azim (2015) menunjukkan bahwa perusahaan melakukan manajemen laba ketika mereka lebih banyak memberikan pengungkapan CSR. Namun untuk industri berorientasi export yang didominasi oleh pembeli internasional pengungkapkan yang banyak atas akitivas CSR dapat memberikan laporan keuangan yang transparan melalui pembatasan manajemen laba.

Ketika perusahaan melakukan manajemen laba, maka perusahaan akan memberikan banyak pengungkapan. Namun disisi lain pengungkapan yang banyak tersebut dapat menyebabkan biaya yang tinggi sehingga berdampak juga pada kinerja keuangan. Perusahaan dengan tingkatan yang berbeda memiliki tingkat manajemen laba yang berbeda pula. Dengan menggunakan discretionary accrual dalam mengukur manajemen laba, Hastuti (2010) menemukan bahwa perusahaan dengan tingkat siklus hidup perusahaan yang stagnan kurang melakukan manajemen laba dari pada yang dilakukan perusahaan yang dewasa.

Wardani dan Kusuma (2012) menginvestigasi pengaruh manajemen laba terhadap kemampulabaan masa depan (future profitability) di negara-negara ASEAN dengan menggunakan 2 pengukuran manajemen laba yaitu real earning management dan accrual earning management. Hasilnya menunjukkan bahwa karakteristik manajemen laba tidak konsisten. Manajemen laba rill bersifat informasional di Thailand, tapi oportunistik di Indonesia. Manajemen laba akrual bersifat informasional di Filipina, tapi oportunistik di Malaysia 


\section{Pengembangan Hipotesis \\ Corporate Social Responsibility dan Kinerja Keuangan}

Demacarty (2009) menemukan bahwa ada korelasi positif antara CSR dan kinerja keuangan perusahaan. Walaupun ia juga menjelaskan bahwa temuan itu bukan saja disebabkan adanya CSR namun karena kemampuan manajemen. Penelitian lain yang dilakukan Chen dan Wang (2011) menunjukkan bahwa aktivitas tanggungjawab sosial perusahaan dapat meningkatkan kinerja keuangan tahun berjalan dan memiliki pengaruh signifikan pada kinerja keuangan tahun berikutnya dan sebaliknya. Dari hasil penelitian tersebut maka hipotesis pertama yang akan diuji adalah

H1 Corporate Social Responsibility berpengaruh signifikan pada kinerja keuangan

\section{Manajemen laba dan Corporate Social Responsibility}

Pada umumnya manajemen laba dapat dikategorikan menjadi dua yaitu; (1) manajemen laba riil dan (2) manajemen laba akrual (Christensen dalam Senjani, 2013). Perusahaan dalam hal ini manajemen, melakukan manajemen laba dengan berbagai motivasi. Salah satunya adalah untuk meningkatkan kemakmuran manajemen. Perusahaan yang banyak melakukan manajemen laba akan lebih banyak melakukan pengungkapan tanggungjawab sosial. Manajemen laba berpengaruh secara posistif signifikan pada pengungkapan Corporate Social Responsibility setelah dikontrol oleh ukuran perusahaan dan tipe industri (Handajani, Sutrisno, Chandrarain; 2009)

$\mathrm{H} 2 \mathrm{a} \quad$ Real Earning Management (REM) berpengaruh signifikan pada Corporate Social Responsibility

$\mathrm{H} 2 \mathrm{~b} \quad$ Discretionary Accruals (DA) berpengaruh pada Corporate Social Responsibility

\section{Manajemen laba memoderasi hubungan antara CSR dan Kinerja Keuangan}

Ketika perusahaan melakukan manajemen laba, maka perusahaan akan memberikan banyak pengungkapan. Namun disisi lain pengungkapan yang banyak tersebut dapat menyebabkan biaya yang tinggi sehingga berdampak juga pada kinerja keuangan. Perusahaan dengan tingkatan yang berbeda memiliki tingkat manajemen laba yang berbeda pula. Dengan menggunakan discretionary accrual dalam mengukur manajemen laba, Hastuti (2010) menemukan bahwa perusahaan dengan tingkat siklus hidup perusahaan yang stagnan kurang melakukan manajemen laba dari pada yang dilakukan perusahaan yang dewasa. Pada penelitian ini manajemen laba tidak hanya diukur menggunakan discretionary accruals namun juga menggunakan real earning management. Sehingga hipotesis selanjutnya yang akan diuji adalah

$\mathrm{H} 3 \mathrm{a}$ Real Earnings Management memoderasi hubungan antara Corporate Social Responsibility dan kinerja keuangan

$\mathrm{H} 3 \mathrm{~b} \quad$ Discretionary Accruals memoderasi hubungan antara Corporate Social Responsibility dan kinerja keuangan

\section{METODE PENELITIAN \\ Populasi dan Sampel}

Populasi yang digunakan dalam penelitian ini adalah semua perusahaan manufaktur yang terdaftar di Bursa Efek Indonesia (Indonesia Stock Exchange atau IDX). Pemilihan sampel penelitian berdasarkan metode purposive sampling. Adapun kriteria yang harus dipenuhi adalah sebagai berikut: 
1. Perusahaan sampel terdaftar di Bursa Efek Indonesia tahun 2011-2015 dalam kelompok industri manufaktur yang menerbitkan laporan tahunan (annual report) secara berturut-turut.

2. Perusahaan sampel mempunyai laporan keuangan yang berakhir 31 Desember dan menggunakan rupiah sebagai mata uang pelaporan.

3. Perusahaan sampel memperoleh laba selama tahun pengamatan.

4. Perusahaan sampel melakukan pengungkapan CSR dalam laporan tahunan secara berturut-turut selama tahun 2011-2015.

5. Perusahaan sampel memiliki semua data yang diperlukan secara lengkap.

\section{Data dan Sumber Data}

Data pada penelitian ini merupakan beberapa informasi yang diperoleh dari laporan keuangan perusahaan manufaktur yang terdaftar di Bursa Efek Indonesia (IDX). Laporan keuangan diperoleh dari situs resmi IDX.

\section{Pengukuran Variabel}

Kinerja keuangan yang diproksikan menggunakan Return on Asset (ROA) mengacu pada penelitian yang dilakukan oleh Sarumpaet (2005). ROA adalah rasio Laba bersih sebelum pajak dibagi total asset.

Real earning management diukur menggunakan model manajemen laba Roychowdury's (Roychowdury's, 2006). Proxy untuk real earning management adalah arus kas operasi abnormal (Abn CFO) biaya produksi abnormal (Abn prod) beban diskresi abnormal (Abn Disc Exp). Proses untuk menghitung real earning management adalah sebagai berikut:

1. Hitung arus kas operasi abnormal (CFO)

a. Menghitung arus kas operasi normal sebagai fungsi linier dari penjualan dan

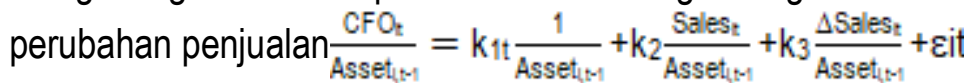

b. Menghitung $\mathrm{CFO}$ abnormal CFO abnormal adalah perbedaan antara arus kas aktual dan arus kas normal. Abn CFO = Actual CFO - Normal CFO

2. Menghitung biaya produksi abnormal

a. Menghitung biaya produksi normal yang didefinisikan sebagai jumlah dari harga pokok penjualan (COGS) dan perubahan

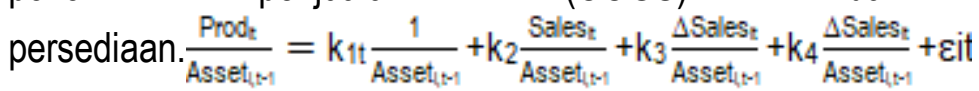

b. Menghitung biaya produksi abnormal

Biaya produksi abnormal adalah perbedaan antara biaya produksi actual dengan biaya produksi normal.

Abn Prod Cost $=$ Act Prod Cost - Normal Prod Cost

3. Menghitung beban diskresi abnormal

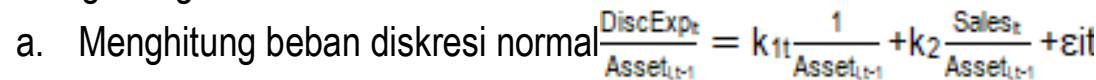

b. Menghitung beban diskresi abnormal

Beban diskresi abnormal adalah perbedaan antara beban diskresi dan beban dikresi normal

Abn Disc Exp $=$ Act Disc Exp - Normal Disc Exp

4. Menghitung real earnings management

$\mathrm{AREAL}_{t} \quad=\mathrm{ACFO}_{t}+\mathrm{APROD}_{\mathrm{t}}+\mathrm{ADISCEXP}_{\mathrm{t}}$ 


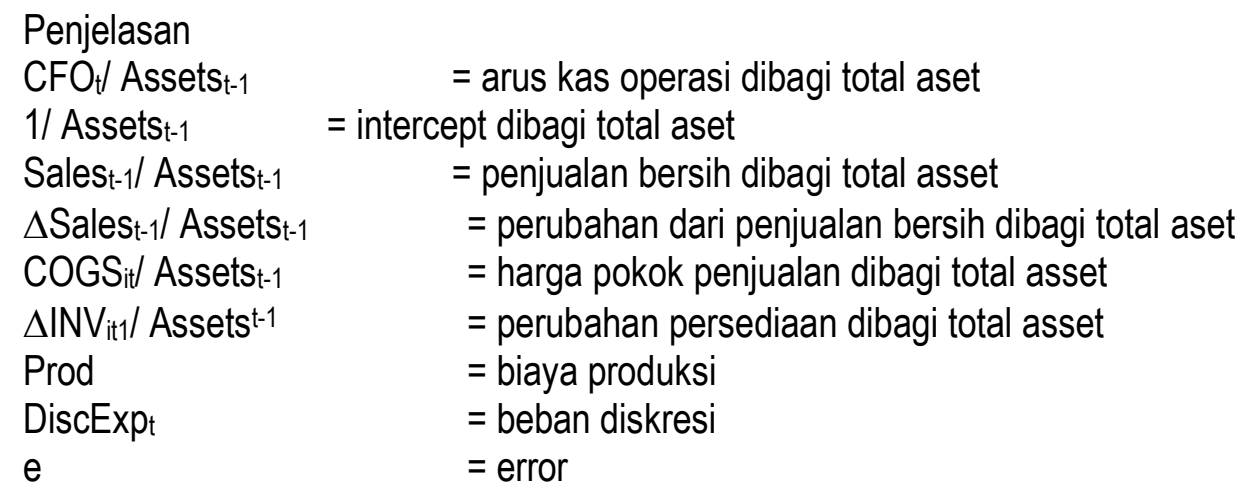

Pengukuran accrual earning management menggunakan proxy discretionary accruals. Discretionary accrual diukur menggunakan modified Jones model (Dechow et al, 1995). Tahapan dalam menghitung discretionary accrual:

1. Menghitung akrual total

TACC $_{\text {it }}$ $=\mathrm{EBXT}_{\text {it }}-\mathrm{CFO}_{\text {it }}$

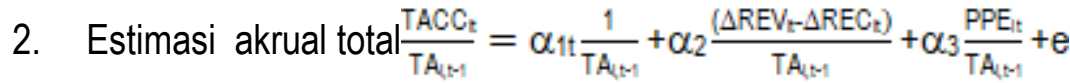

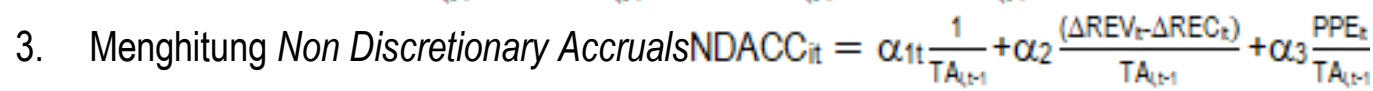

4. Discretionary accrualsDACG $=\left(\frac{T_{A} A_{t}}{T_{A N A}}\right)-$ NDACG $_{t}$

Penjelasan:

DACC $_{\text {it }}=$ Discretionary Accruals

NDACC $_{\text {it }} \quad=$ Non Discretionary Accruals

TACC $_{\text {it }} \quad=$ Total Accruals

Tat $-1 \quad=$ Aset total

EBXT it $_{\text {it }} \quad=$ Laba sebelum item luar biasa dan pajak

$\mathrm{CFO}_{\text {it }} \quad=$ Arus kas operasi

$\triangle R V_{t} \quad=$ Perubahan pendapatan

$\mathrm{PPE}_{\mathrm{t}} \quad=$ Property, Plant and Equipment

$\triangle$ REC $_{t} \quad=$ Perubahan piutang

Global Reporting Initiatives (GRI) sebagai Proxy pengungkapan CSR. Indikator GRI digunakan adalah: ekonomi ( 9 item), lingkungan (30 item), praktik tenaga kerja (14 item), hak asasi manusia (9 item), masyarakat (8 item) dan tanggung jawab produk ( 9 item). Total item pengungkapan CSR menurut GRI adalah 79. ICSR dari setiap perusahaan dihitung sebagai berikut:

$\operatorname{ICSR}_{\mathrm{j}}=\frac{\sum_{t=1}^{n j} \mathrm{X}_{\mathrm{ij}}}{\mathrm{n}_{\mathrm{j}}}$

dimana ICSR adalah index pengungkapan CSR dari perusahaan $\mathrm{j}, \mathrm{n}$ adalah jumlah itempengungkapan untuk perusahaan j, dan nj adalah 79, Xij adalah 1 jika item I diungkapkan, dan 0 jika tidak diungkapkan. Sehingga $0<\mathrm{ICSRj}<1$.

\section{Teknik Analisis Data}

Pengujian hipotesis diuji dengan menggunakan alat analisis regresi linear sederhana (simple regression linear). Dilakukan regresi untuk masing-masing hipotesis. Persamaan regresi yang digunakan adalah sebagai berikut: 
Untuk Hipotesis 1

$\mathrm{ROA}=\beta_{0}+\beta_{1} \mathrm{CSR}+\mathrm{e}$

Untuk Hipotesis 2a

$\mathrm{CSR}=\beta_{0}+\beta_{1}$ AREAL $+e$

Untuk Hipotesis $2 b$

$\mathrm{CSR}=\beta_{0}+\beta_{1} \mathrm{DACC}+\mathrm{e}$

Untuk Hipotesis $3 a$

$\mathrm{ROA}=\beta_{0}+\beta_{1} \mathrm{CSR}+\beta_{2} \mathrm{AREAL}+\beta_{3} \mathrm{CSR}^{*} \mathrm{AREAL}+\mathrm{e}$

Untuk Hipotesis $\mathrm{H} 3 \mathrm{~b}$

$\mathrm{ROA}=\beta_{0}+\beta_{1} \mathrm{CSR}+\beta_{2} \mathrm{DACC}+\beta_{3} \mathrm{CSR}^{*} \mathrm{DACC}+\mathrm{e}$

\section{HASIL DAN PEMBAHASAN}

Berdasarkan kriteria penentuan sample, jumlah sampel pada penelitian ini sebanyak 47 perusahaan dengan 235 observasi. Dari 235 data, ada 5 yang dikeluarkan dari sampel. Model regresi dalam penelitian ini sudah memenuhi uji asumsi klasik yaitu multikolinieritas, heteroskedastisitas, autokerelasi dan normalitas. Tabel 1 menunjukan hasil pengujian hipotesis 1

Tabel 1

\begin{tabular}{cccc}
\hline Variabel & Coefficient & Probability & $\mathbf{R}^{2}$ \\
Constant & 0.136 & 0.000 & \\
CSR & 0.012 & 0.870 & 0.000 \\
\hline
\end{tabular}

Hasil uji model regresi diperoleh nilai nilai koofisien determinan ( $R$ square) sebesar 0.000 yang menunjukkan bahwa variabel CSR menjelaskan $0 \%$ variabel ROA, dan sisanya dijelaskan variabel lain. Hipotesis pertama menunjukkan koefisien 0,012 dan $p$ value 0,870 yang berarti CSR berpengaruh positif, tapi tidak signifikan. Secara empiris hipotesis ini tidak didukung. Perusahaan yang memiliki kinerja keuangan yang baik tidak semata-mata mengandalkan aktivitas sosialnya saja, namun juga keahlian manajemen dalam mengelola perusahaan. Manajemen yang memiliki keahlian yang tinggi dalam menyusun strategi untuk meningkatkan produktivitas perusahaan akan mendorong meningkatnya kinerja keuangan. Tabel 2 menunjukan hasil pengujian hipotesis $2 a$ sebagai berikut:

Tabel 2

\begin{tabular}{cccc}
\hline Variabel & Coefficient & Probability & $\mathbf{R}^{2}$ \\
Constant & -4.185 & 0.000 & \\
REAL & -0.38 & 0.327 & 0.005 \\
\hline
\end{tabular}

Hasil uji model regresi untuk hipotesis 2a diperoleh nilai koofisien determinan ( $R$ square) sebesar $0.005(0.5 \%)$ yang menunjukkan bahwa variabel Real Earnings Management menjelaskan $0.5 \%$ variabel CSR, dan sisanya dijelaskan variabel lain. Hipotesis 2a menunjukkan koefisien -0.38 dan $p$ value 0.327 yang berarti Real Earning Management berpengaruh negatif, tapi tidak signifikan. Secara empiris hipotesis ini tidak didukung karena $p$ value $>0.05$. Tabel 3 menunjukan hasil pengujian hipotesis $2 \mathrm{~b}$ sebagai berikut:

Tabel 3

\begin{tabular}{llll}
\hline Variabel & Coefficient & Probability & $\mathbf{R}^{2}$ \\
Constant & -3.661 & 0.000 & \\
DACC & 0.115 & 0.059 & 0.18 \\
\hline
\end{tabular}

Hal. 69 
Hasil uji model regresi untuk hipotesis $2 b$ diperoleh nilai koofisien determinan ( $R$ Square) sebesar $0.18(18 \%)$ yang menunjukkan bahwa variabel Discretionary accruals menjelaskan $18 \%$ variabel CSR, dan sisanya dijelaskan variabel lain. Untuk hipotesis $2 \mathrm{~b}$ menunjukkan koefisien 0.115 dan $p$ value 0.59 yang berarti Discretionary accruals berpengaruh positif, tapi tidak signifikan. Secara empiris hipotesis ini tidak didukung karena $p$ value $>0.59$. Hasil penelitian ini menunjukkan baik manajemen laba bentuk riil maupun bentuk akrual diskresi tidak mempengaruhi CSR. Perusahaan memiliki motivasi yang berbeda untuk melakukan managemen laba dan tanggungjawab sosial. Manajemen laba bisa saja dilakukan untuk tujuan meningkatkan kemakmuran manajemen, sedangkan tanggungjawab sosial dilakukan agar perusahaan dapat bertahan dimasa yang akan datang. Hasil penelitian ini mendukung penelitian Rahmahwati dan Dianita (2011) bahwa manajemen laba tidak berpengaruh pada CSR. Tabel 4 menunjukkan hasil pengujian hipotesis 3 a sebagai berikut :

Tabel 4

\begin{tabular}{cccc}
\hline Variabel & Coefficient & P Value & $\mathbf{R}^{2}$ \\
Constant & 0.149 & 0.000 & \\
REAL & 0.008 & 0.395 & 0.50 \\
CSR & -0.154 & 0.76 & \\
REAL X CSR & -0.153 & 0.023 & \\
\hline
\end{tabular}

Hasil uji model regresi diperoleh nilai nilai koofisien determinan ( $R$ square) sebesar 0.50 (50\%) yang berarti real earning management, CSR dan interaksi Real Earning Management dan CSR dapat menjelaskan $50 \%$ variasi dari kinerja keuangan. Hasil uji F ANOVA menunjukan nilai 0.019 dan siginifkan pada level $5 \%$, yang berarti model regresi cocok digunakan untuk model prediksi kinerja keuangan atau dapat dikatakan REM, CSR dan interaksi REM dan CSR secara bersama berpengaruh pada kinerja keuangan perusahaan. Hipotesis 3a menunjukkan bahwa koefisien interaksi variabel Real Earnings Management dan CSR (REALx CSR) adalah negatif yaitu -0.153 dan $p$ value 0.023 . Ini mengindikasikan bahwa interaksi antara real earning management dan CSR berpengaruh/ negative pada kinerja keuangan dan secara empiris didukung pada level 5\%. Sehingga hipotesis 3a diterima. Hasil ini mengitepretasikan bahwa semakin tinggi manajemen laba maka CSR akan meningkat dan memperburuk kinerja keuangan dimasa depan, karena CSR digunakan oleh manajemen untuk menutupi praktik manajemen laba. Tabel 5 menunjukkan hasil pengujian hipotesis $3 \mathrm{~b}$ sebagai berikut:

Tabel 5

\begin{tabular}{cccc}
\hline Variabel & Coefficient & P value & $\mathbf{R}^{2}$ \\
Constant & 0.121 & & \\
DACC & 0.177 & 0.165 & \\
CSR & -0.58 & 0.697 & 0.45 \\
DACC X CSR & 0.075 & 0.925 & \\
\hline
\end{tabular}

Hasil uji model regresi diperoleh nilai nilai koofisien determinan ( $R$ square) sebesar 0.45 (45\%) yang berarti Discretionary Accruals, CSR dan interaksi Discretionary Accruals dan CSR dapat menjelaskan 45\% variasi dari kinerja keuangan. Hasil uji F ANOVA menunjukan nilai 0.032 dan siginifkan pada level $5 \%$, yang berarti model regresi cocok digunakan untuk model prediksi kinerja keuangan atau dapat dikatakan DACC, CSR dan interaksi DACC dan CSR secara bersama berpengaruh pada kinerja keuangan perusahaan. Hipotesis $3 b$ menunjukkan bahwa koefisien interaksi variabel Discretionary Accruals dan CSR (DACCx CSR) adalah negatif yaitu - 
0.075 dan $p$ value 0.925 . Ini mengindikasikan bahwa interaksi antara Discretionary Accruals dan CSR tidak berpengaruh pada kinerja keuangan dan secara empiris tidak didukung pada level $5 \%$. Sehingga hipotesis $3 \mathrm{~b}$ gagal didukung.

\section{SIMPULAN}

Penelitian ini bertujuan untuk menganalisa dan memperoleh bukti empiris tentang pengaruh manajemen laba atas tanggungjawab sosial perusahaan. Penelitian ini juga bertujuan untuk menguji apakah tanggung jawab sosial perusahaan yang terkait dengan manajemen laba mempengaruhi kinerja keuangan. Berikut ini adalah kesimpulan dari hasil pengujian hipotesis:

a. Pengujian hipotesis pertama tidak dapat didukung yang berarti Corporate Social Responsibility tidak berpengaruh pada kinerja keuagan

b. Pengujian hipotesis kedua (a) tidak didukung yang berarti manajemen laba riil tidak berpengaruh padaCorporate Social Responsibility

c. Pengujian hipotesis kedua (b) tidak didukung yang berarti manajemen laba discretionary accruals tidak berpengaruh pada Corporate Social Responsibility

d. Pengujian hipotesis ketiga (a) didukung, yang berarti Corporate Social Responsibility yang dihubungkan dengan manajemen laba riil berpengaruh pada kinerja keuangan

e. Pengujian hipotesis ketiga (b) didukung, yang berarti Corporate Social Responsibility yang dihubungkan dengan manajemen laba discretionary accruals tidak berpengaruh pada kinerja keuangan

Beberapa keterbatasan dalam penelitian ini antara lain:

a. Hasil dari uji hipotesis menunjukkan nilai R2 yang cenderung kecil. Hal ini kemungkinan disebabkan tidak dimasukkannya variabel kontrol yang secara teori dapat mempengaruhi ROA maupun CSR seperti ukuran perusahaan, leverage, kepemilikan institusional dan kepemilikan publik. Periode pengamatan yang digunakan pada penilitian ini adalah dari 2011 sampai dengan 2015.

b. Pada periode pengamatan ini ada peralihan penggunaan standar akuntansi, yaitu konvergensi IFRS yang efektif pada 2012. Kondisi ini diasumsikan dapat mempengaruhi data yang digunakan dalam penelitian ini. Oleh karena itu pada penelitian sebelumnya dapat dilakukan pengamatan setelah konvergensi IFRS efektif diterapkan yaitu diatas tahun 2012.

\section{UCAPAN TERIMAKASIH}

Terimakasih kami ucapkan kepada mahasiswa-mahasiswa kami yang ikut membantu dalam mengumpulkan data pada penelitian ini yaitu Randy Kuswanto dan Anggi Trisna Riani.

\section{DAFTAR PUSTAKA}

Albinger, Heather Schmidt \& Freeman, Sarah F. 2000. Corporate social performance and attractivenss as an employer to different job seeking population. Journal of Business Ethics (28)

Al khabash, Ahmed A \& Ali. A. Al Thuneibat. 2009. Earning management practice of external and internal auditors. Management and auditing journal. Vol 24, No.1

Aras, Güler., Asli Aybars., Ozlem Kutlu. 2010. Managing Corporate Performance: Investigating the relationship between corporate social responsibility and financial performance in emerging markets. International Journal Productivity. Vol 59 No 3 pp 229-254 
Bassamalah, Anies S \& Johnny Jermias. 2005. Social and environmental reporting and auditing in Indonesia: Maintaining Organizational Legitimacy?. Gadjah Mada International Journal of Business. January-April Vol. 7 No. 1. pp: 109 - 127.

Chairi, Anis., Nugroho, Firman Aji. 2009. Retorika dalam pelaporan corporate social responsibility: Analisis semiotik atas sustainability reporting PT. Aneka Tambang Tbk. 46 Mei Simposium Nasional Akuntansi XII

Chen, Honghui \& Xiayang Wang. 2011. Corporate social responsibility and corporate financial performance in China. An empirical research from Chinese firm. Academic paper. Corporate Governance. Vol 11, No.4

Crisostomo, Vicente Lima., Fatima de Souza Freire and Felipe Cortes de Vasconcellos. 2011. Corporate social responsibility, firm value and financial performance in Brazil. Social Responsibility Journal. Vol 7 No 2 pp 295-309

Demacarty, Peter. (2009). Financial returns of corporate social responsibility, and the moral freedom and responsibility of business leaders. Business and Society review

Decow, P.M., R.G Sloan and AP Sweeney. 1995. Detecting earning management. Accounting Review 70 (2): 193-225

Handajani, Lilik., Sutrisno \& G Chandrarin. 2009. The effects of earning management \& good corporate governance mechanism on corporate social responsibility disclosure. An empirical study at public companies in Indonesian stock exchange. The Indonesian Journal of Accounting Research. Vol 12, No.3

Ikatan Akuntan Indonesia. 2014. Pernyataan Standar Akuntansi Keuangan No 1. Standar Akuntansi Keuangan Per Efektif 1 Januari 2015

Irina., Ndash., lamandi Eugenia., Gin, Andreea Raluca., Chiciudean., Alina \& Go, Mihaela Cristina. 2010. Corporate Social Responsibility - Analyzing Social and Financial Performance The Case of Romania. European research studies journal

Itkonen, L. (2003). Corporate Social Responsibility and Financial Performance. Hilsinki: Institute of Strategy and InternationalBusiness

Kiattikulwattana, Prapaporn. 2014. Earning management and voluntary disclosure of management's responsibility for the financial reports. Asian Review of Accounting, Vol 22 Iss 3 pp.233-256

Kolodinsky, Robert W., Madden, Timothy M., Zisk, Daniel S., Henkel, Erick T. 2010. Attitudes about corporate social responsibility. Business student predictor. Journal of Business Ethics (91)

Mangoting, Yenni. 2007. Biaya Tanggung Jawab Sosial sebagai Tax Benefit. Jurnal Akuntansi dan Keuangan Vol.9. Fakultas Ekonomi Universitas Kristen Petra.

Mulford, Charles W \& Eugene E. Comiskey. 2010. Deteksi Kecurangan Akuntansi. The Financial Numbers Game. PPM Manajemen

Muttakin, Muhammad Badrul., Arifur Khan., Mohammad I. Azim. 2015. The influence of corporate social responsibility disclosure on share prices: Evidence from United Kingdom. Pacific Accounting Review. Vol 27 Iss 2 pp 208-228

Rahmawati \& Putri Septa Dianita. 2011. Analysis of the effects of Corporate social responsibility on financial performance with earning management as a moderating variable. Journal of Modern Accounting Auditing. Vol 7, No.10

Rettab, Balaid., Brick, Anis Ben \& Melahi, Kamel. 2009. Study of management perceptions of the impact of corporate social responsibility on organizational performance in emerging economies: the case of Dubai. Journal of business ethics

Riahi, Ahmed \& Belkaoui. 2006. Teori akuntansi. Edisi 5. Penerbit Salemba 
Roychowdhury, S. 2006. Earning management through real activities manipulation. Journal of Accounting and Economics. 42 pp 335-370

Sarumpaet, Susi. 2005. The relationship between environmental performance and financial performance of Indonesian companies. Jurnal Akuntansi dan Keuangan. Vol. 7, No.2, November. Universitas Kristen Petra

Senjani, Yayu Putri. 2013. Manajemen laba akrual dan riil sebelum dan setelah adopsi wajib IFRS di Uni Eropa. Jurnal Etikonomi, Vol 12 No.1

Usman, Aliyu Baba., Noor Afza Binti Amran. 2015. Corporate social responsibility practice and corporate financial performance. Social Responsibility Journal, Vol 11 Iss 4 pp 749-763

Waddock, S. A \& S. M. Graves. (1997). The corporate social performance Financial performance link. Strategic Management Journal18 (4)

Wardani, Dewi Kusuma dan Indra Wijaya Kusuma. 2012. Is earning management informational or opportunistic? Evidence from ASEAN countries. Gadjah Mada International Journal of Business. Vol 14 No 1

Wibisono, Y., 2007. Membedah konsep \& kplikasi CSR: Corporate social responsibility. Jakarta: Fascho Publishing.

Mangoting, Yenni. 2007. Biaya tanggung jawab sosial sebagai tax benefit. Jurnal Akuntansi dan Keuangan. Mei-Vol. 9, NO. 1. Universitas Kristen Petra

Yuniarsih, Ni wayan \& Wirakusuma, Made Gede. 2009. Pengaruh kinerja keuangan terhadap nilai perusahaan dengan pengungkapan corporate social responsibility dan good corporate governance sebagai variabel moderasi. Media AUDI Jurnal Akuntansi dan Bisnis. Januari-Vol.4. No.1. Universitas Udhayana 